\title{
THE CHANGE OF THE TRAJECTORY TOWARDS GROWING ECONOMY: THE EVIDENCE FROM RUSSIA
}

\author{
Milos Bikar ${ }^{1, a}$ and Mariana Sedliacikova, ${ }^{2, b, *}$ \\ ${ }^{1}$ University of Economics in Bratislava, Faculty of Business Management, Dolnozemská cesta 1, \\ 85235 Bratislava, Slovak Republic \\ ${ }^{2}$ Technical University in Zvolen, Faculty of Wood Sciences and Technology, Ul. T.G.Masaryka 24, \\ 96053 Zvolen, Slovak Republic \\ amilos.bikar@euba.sk, bsedliacikova@tuzvo.sk \\ *Corresponding author
}

Cite as: Bikar, M., Sedliacikova, M. (2018). The change of the trajectory towards growing economy: The evidence from Russia, Ekonomicko-manazerske spektrum, 12(2), 26-36.

Available at: dx.doi.org/10.26552/ems.2018.2.26-36

\begin{abstract}
The Russian economy has overcome the recession and returned to moderate growth in year 2017, as the economy has adjusted to the lower oil price and the sanctions imposed in 2014. Russian companies had stepped up domestic investment, attracted by industrial policy incentives and a weak rouble that increased their competitiveness. A resilient rubble and steady oil prices have given the central bank room for a rate cut. The medium-term growth forecast for Russia has slightly improved after a faster-than-expected recovery in demand on the domestic market and due to higher exports. Monetary policy should be eased to support growth, but cautiously to avoid a rebound of inflation. The paper deals with the analyses and predictions of the Russian economy development and the main factors influencing the current and future economy and the GDP structure. The objective of this article was to analyse the time-varying nature among Russian GDP, oil prices and some major macroeconomic variables. The results of the carried out research reflected that the oil prices has played a key role and has indeed changed the nature of correlation relationship between analysed variables. The value of the rubble against dollar is closely tied to the price of oil, Russia's main export. Over the longer term growth is expected to continue lagging behind the world average unless the government adopts decisive structural reforms to boost investment. The poverty rate will gradually decline as the labor market strengthens and inflation abates further. The paper highlights the monetary policy including currency prediction, public debts, and inflation levels, as well as commodity export dependency.
\end{abstract}

Keywords: GDP, Commodity prices, exchange rate volatility, public finances

JEL Classification: F34, G15, H60

\section{Introduction}

The recovery in Russia is definitely taking place, as the economy has adjusted to the lower oil price and the sanctions imposed in 2014. Growth reached an annual rate of $2.5 \%$ in the second quarter 2017, the fastest in almost five years. Last year Russia received 12.9 billion USD in foreign direct investment, making it the third-largest recipient of FDI in Europe after the UK and France (World Bank, 2017). Russian companies had stepped up domestic investment, attracted by industrial policy incentives and a weak rouble that increased their competitiveness. Fixed asset investment started growing year on year in April 2017 after 
shrinking for more than three years. Financial investors had also started viewing Russia more favourably. By mid-2015, a year after the 2014 sanctions, risk managers in western banks took the view that the situation had stabilised and legal risks had come down sufficiently.

Nevertheless, the new applied US law tightens restrictions on lending to certain state banks and energy companies, expand energy sanctions and creates risk for a future period (Matyeeva, 2018). The biggest damage could be caused by broadening capital market sanctions to Russian sovereign debt. Non-residents held $30.7 \%$ of total federal government debt as of June 1, 2017 (Russian Central Bank, 2017). The proportion is above $50 \%$ in bonds issued last year and this year, and with more than $70 \%$ in bonds with a maturity above seven years. This is driven by the very high interest rate differential between the Russian Federation and the rest of the world.

The Russia economy has drawn the attention of investors, policy makers and research academics across the world. Several studies have focused on the correlation between the commodity prices and the Russia economic output, dependency of oil prices and state budget development, the general economic environment and foreign direct investment and currency volatility and reactions to different shock scenarios.

Conceptual views on the Russia economic development are similar and point out on the one hand, an inevitable structural reforms across all economy and industry sectors and on the second hand, strong correlation between input commodity prices and achieved economic results (Gaddy \& Ickes, 2010, Papava, 2018). As confirmed by the study of Bikar (2013), Russia's oil and gas give an unmatched source for generating wealth. The problem is, how those source are used, mainly how inefficient sector and companies as addictive are laying claims to an inordinate share of the rents, and how to restrain the addiction to the ensuing rents. The problem for Russia is how to move away from addiction within the confines of the rent management system that Putin has created. The research studies of Kudrin \& Gurvich (2015) and Kohlscheen et al. (2016) found out that commodity markets substantially accelerated output growth allowed record increases in incomes (wages for all sectors of the economy, including the public sector, pensions, etc.) and improved macroeconomic stability. However, significant resources aimed at modernizing the economy failed to produce tangible results, as Russia's international competitiveness has not fundamentally improved. This casts doubt on the possibility that a resource approach can foster conditions for long-term economic growth. They came to a conclusion that even if oil prices suddenly recover rapidly, the Russia model based on imported growth would still fail to ensure economic growth. Bouoiyour et al. (2015) analysed the nexus between oil price and Russia's real exchange rate via unconditional versus conditional analysis. A major finding of this paper is deeply suggestive of a sharp causality running from oil price to real exchange rate in lower frequencies. This implies that Russia should better tackle with turbulence triggered by oil price and continue to reduce its energy dependency via drastic and proactive measures.

Bogetic \& Olusi (2013) carried out the research study analysing the divers of firm-level productivity in Russia's manufacturing sector using Cobb-Douglas production function. They found out, that productivity grew steadily between 2003 and 2008, with an annual growth rate averaging $4 \%$ over the period, showing no signs of a slowdown from the previous period after the 1998 crisis. Gonzalez et al. (2013) applied a model searching up factors influencing the Russian volatility. They proved that Russian manufacturing output growth is characterized by a higher volatility than other comparator countries. Higher volatility is mostly driven by the presence of more numerous, deeper and longer slumps and is mostly associated with aggregate slumps with yearly effects. In addition, as shown by study of Reisinger \& Moraski (2013) and Sharafutdinova \& Kisunko (2014), the Russia is characterized by close informal ties between the authorities and business. In means, that the regional diversity in business climate - regional 
location was found to be significantly correlated with firms' perceptions of administrative burden, corruption, and state capture indicators.

In a more recent study, Deev \& Hodula (2016) investigated the interdependence of the sovereign default risk and banking system fragility in Russia, using credit default swaps as a proxy for default risk. The typical feature is that the biggest state-owned universal banks in emerging markets are closely managed by the government. But the fragility of those banks does not directly affect the state of public finances. However, in cases where state-owned banks directly participate in large governmental projects, banking fragility may result in the deterioration of state funds, while raising the risk of sovereign default. Mau (2016) analysed an anti-crisis measures and effect of the external shocks for the key Russian export products and claims, that there were serious structural problems that have reduced growth potential since the middle of the past decade, and have caused stagnation in the Russian economy.

Another aspect of the economy is connected with the Russia's defence spending. According to study of Oxenstierna (2016), behind the rise in the defence budget was the new state armament program 2011-2020, with the ambition, that by 2020, $70 \%$ of the Armed Forces' arms were to be modern. However, the failure to modernize the economy and make it less dependent on hydrocarbons and more innovative led to weak growth after 2009, which means that rising defence spending has become more costly to the economy. The substance of the Russian economy in a near future, would still be heavily dependent on the oil prices (Kudrin, 2013). As confirmed by the study of Jacks (2013), greater volatility is a slightly more certain prospect for real commodity prices in the future. He assumes, that anything can be done to mitigate this volatility in a coordinated fashion either through market or policy mechanisms, this volatility will certainly continue to affect the growth prospects of nations, particularly those which are commodity exporters and which have relatively low levels of financial development.

The latest research study of Ono (2017) examines the finance-growth nexus in Russia with the vector autoregression model, taking oil prices and foreign exchange rates into account. The results suggest that there is causality from economic growth to money supply and bank lending, which implies demand-following responses. The paper empirically supports the claim that Russian banks do not play the role of leading economic growth.

The paper deals with the analyses and predictions of the Russian economy development and the main factors influencing the current and future economy and the structure of GDP. The objective of this article is to analyse the time-varying nature among Russian GDP, oil prices and some major macroeconomic variables.

\section{Data and Methodology}

To suggest the regression model, it was required a use of methods of summary, synthesis and analogy of the knowledge and creation of a short literature review. Second, it was done a data collection. In our model there were used yearly data and our time series range from 1996 to 2017 (22 observations). While similar studies generally use quarterly data, we decided to work on a yearly frequency due to the difficulty of capturing the precise quarterly data. It was used the time series from the QUANDL DataStream.

To capture the dynamics of our model, it was used as a dependant variable GDP output, as a measure of economic activity. Next, it was used Brent crude oil prices (Europe quotes) and consumer price index to include the inflation trend (CPI including regulated prices). Further, the real effective RUB/EUR exchange rate was used to incorporate the monetary policy shock (currency depreciation) into our framework. Last, we incorporated into model the government yearly budget debt and the cumulative debt to GDP to analyse the influence on public finances. 
All variables are in percentage change over the same period in the previous year except an exchange rates. The selected parts of data series are plotted in a Figures 1-3. Regarding the methodology, it was used a method of multiple regression in order to explain the relationship among the independent variables to the dependent variable, according the formula (Hair et al., 2010):

$$
Y=a+b_{1} x_{1}+b_{2} x_{2}+\cdots+b_{x} x_{x}
$$

where $\quad \mathrm{Y}$ is the value of the Dependent variable $(\mathrm{Y})$

$a$ (Alpha) is the Constant or intercept

$\mathrm{b}_{1}$ is the slope (Beta coefficient) for $\mathrm{x}_{1}$

$\mathrm{x}_{1}$ first independent variable that is explaining the variance in $\mathrm{Y}$

$\mathrm{b}_{2}$ is the slope (Beta coefficient) for $\mathrm{x}_{2}$

$\mathrm{x}_{2}$ second independent variable that is explaining the variance in $\mathrm{Y}$, and so on.

The computations were completed in Eviews. Table 1 reports the data, mnemonics, descriptions, sources and specifications.

Table 1: Dataset description

\begin{tabular}{|c|c|c|c|}
\hline Variable & Description & Source & Specification \\
\hline BRENT & $\begin{array}{l}\text { Crude Oil Price: } \\
\text { Brent Europe }\end{array}$ & Quandl & annualized, SA \\
\hline INFLATION & Consumer price index & Quandl & percent, SA \\
\hline RUB_EUR & $\begin{array}{l}\text { Real effective exchange rate } \\
\text { RUB/EUR }\end{array}$ & Quandl & annualized, SA \\
\hline BUDGET_DEBT & $\begin{array}{l}\text { Government Yearly Budget } \\
\text { Debt to GDP }\end{array}$ & Quandl & percent, SA \\
\hline CUMM_DEBT & Cumulative Debt to GDP & Quandl & percent, SA \\
\hline
\end{tabular}

Note: SA=seasonally adjusted

Source: Own production, 2016.

\section{Results}

In this section, the multiple regression estimates for the Russia GDP and chosen independent variables - Brent crude oil, consumer price index, real effective exchange rate RUB/EUR, Government Yearly Budget Debt to GDP and finally Cumulative Debt to GDP. The output from the model confirmed the negative correlation among three selective variables (crude oil, exchange rate and cumulative debt), while two other variables (inflation and government yearly budget debt) show the positive contribution to the economic output.

Experiences have showed that external shocks should be addressed with monetary and fiscal consolidation. Cash injection in such a situation would lead to increasing inflation and undermine, rather than stimulate, investment activity. On the other side, public finance consolidation could function as a brake for inflation growth. This was confirmed by Russia as well, when the inflation in the last two years jumped significantly down, followed by rising GDP trend in this fiscal year (see Fig.1). 
Figure 1: Russia GDP Growth Annual Rate and Monthly Inflation Rate

13

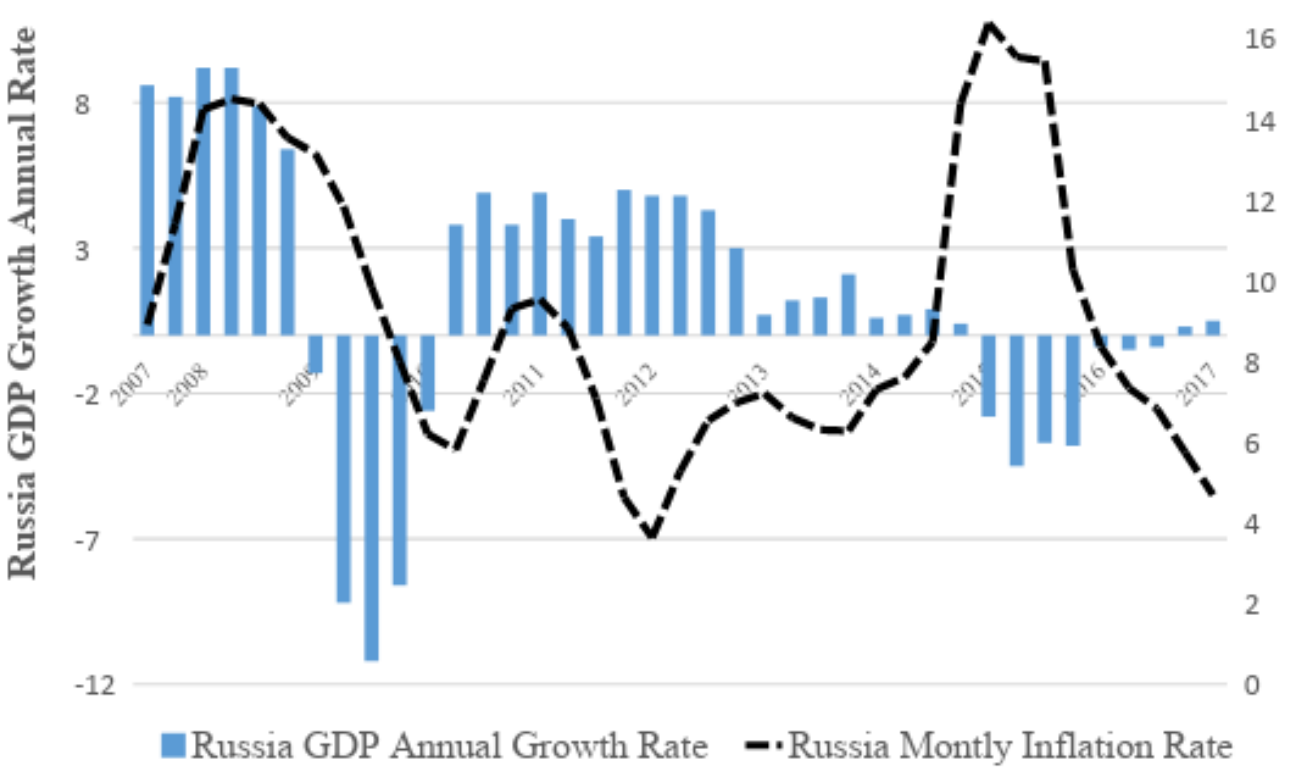

Source: Quandl, 2017.

As the headline inflation has already hit a post-Soviet low of below $4 \%$, the central bank may embark on monetary easing cycle after moving rates down lo lover levels. The influence of economic sanctions supported by lower levels of commodity prices was immediately reflected in a gap of export revenues and deficit of public finances (see Fig. 2).

Figure 2: Russia Government Budget as a \% of the GDP

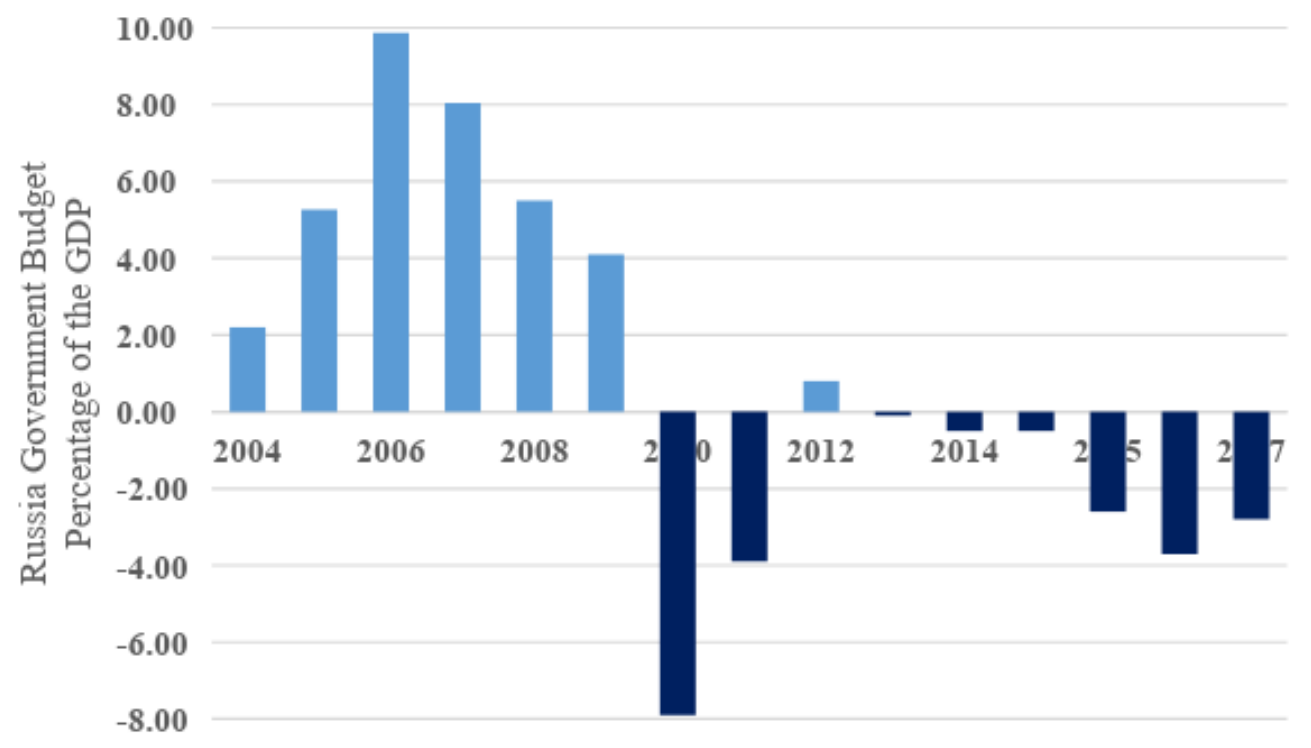

Source: Quandl, 2017.

Russia tend to have a surplus of government budget up to 2009, being able to generate extra sovereign fund, driven mainly by high export commodity prices. But since the global financial crises, the Russia GDP annual growth significantly suffer, and after rapid decline of crude oil 
prices turned to a negative numbers. The highest correlation among macroeconomic variables could be seen between oil prices and currency pair (see Fig.3).

Figure 3: Correlation between Crude Oil Prices Brent and exchange rate EUR/RUB

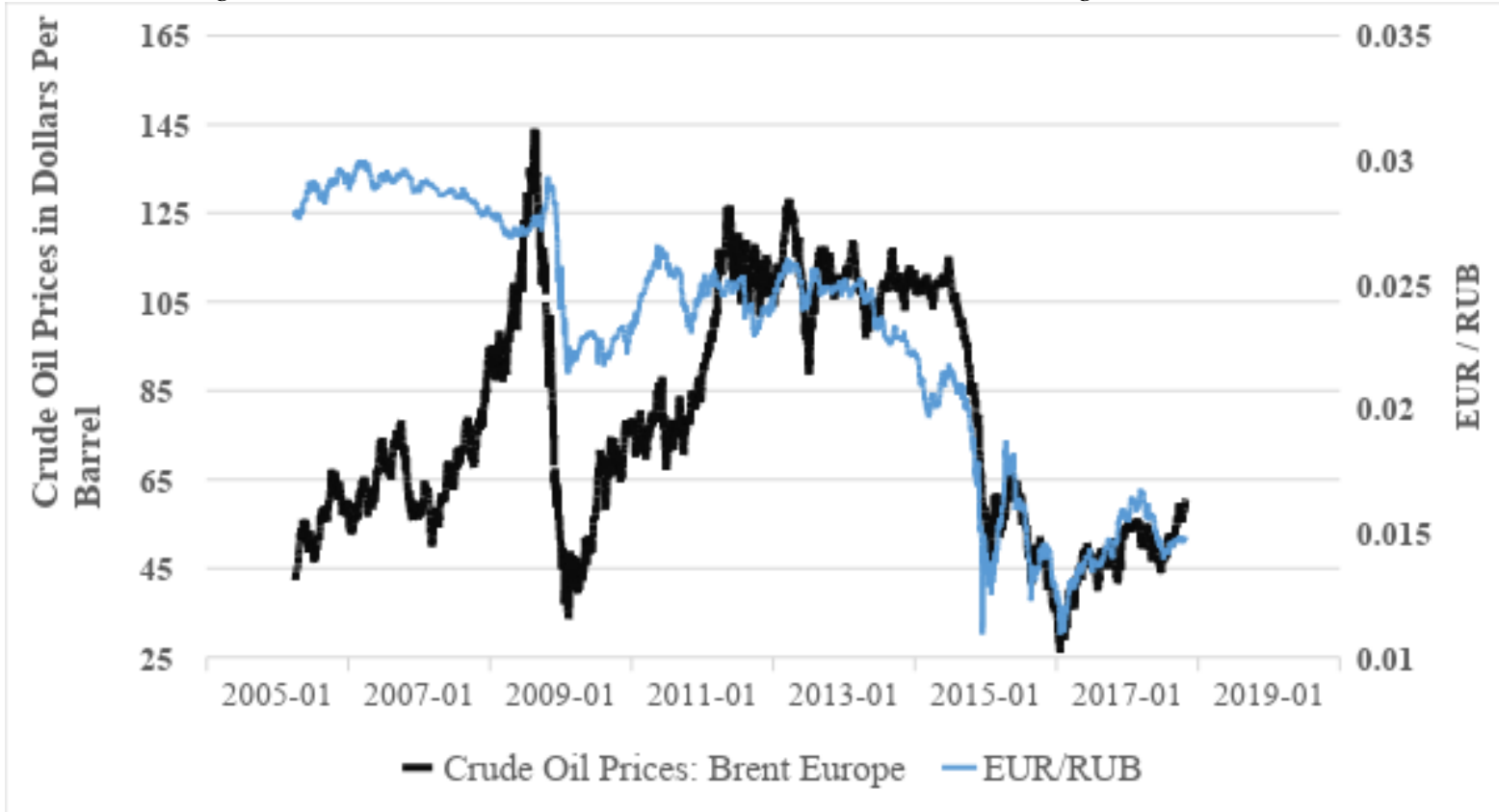

Source: Quandl, 2017.

The next table below summarises the model output including the regression equation.

\section{Table 2: Model output}

Dependent Variable: RUSSIA_GDP_AT_CONSTANT_P

Method: Least Squares

Date: 11/07/17 Time: 21:29

Sample: 19962017

Included observations: 22

\begin{tabular}{lllcc} 
Variable & Coefficient & Std. Error & t-Statistic & Prob. \\
& & & & \\
CRUDE_OIL_PRICES_BRENT & -0.032485 & 0.036126 & -0.899233 & 0.3819 \\
RUB_EUR & -0.142695 & 0.078507 & -1.817603 & 0.0879 \\
RUSSIA_CONSUMER_PRICE_I & 0.027961 & 0.061150 & 0.457257 & 0.6536 \\
RUSSIA_GOVERNMENT_BUDGET & 0.315864 & 0.212435 & 1.486869 & 0.1565 \\
RUSSIA_GOVERNMENT_CUMMUL & -0.083811 & 0.039290 & -2.133138 & 0.0487 \\
C & 12.73419 & 5.563115 & 2.289039 & 0.0360 \\
& & & \\
R-squared & & & \\
Adjusted R-squared & 0.529284 & Mean dependent var & 3.012955 \\
S.E. of regression & 0.382185 & S.D. dependent var & 4.732882 \\
Sum squared resid & 3.720102 & Akaike info criterion & 5.692380 \\
Log likelihood & 221.4265 & Schwarz criterion & 5.989937 \\
F-statistic & -56.61618 & Hannan-Quinn criter. & 5.762475 \\
Prob(F-statistic) & 3.598155 & Durbin-Watson stat & 1.877952 \\
\hline
\end{tabular}

Source: Own calculation (Eviews), 2017. 
The results confirmed the strong dependence of the Russia economy on oil prices. The lower the oil prices, the higher budged debt and cumulative debt as well (Tuzova \& Quayum, 2016). Second, the Russian government debt is less sensitive to FX shocks, and in spite of the Russia cut off from the international markets, the balance of payment gap was primary finance through sufficient FX reserves. The Central Bank of Russia is still able to help the Russian businesses with liquidity in order to roll over their debt.

The Russian economy needs to solve the structural problem via the diversification from the heavy reliance on the export of oil and hydrocarbons, improve the business climate for small and medium-sized enterprises and suppress the corruption (Gurvich, 2013). The modernization program launched in 2009 addressed mentioned problems, but it was too much of a challenge for the ruling political elites and never materialized. It is evident that firms' geographical location matters and that regional variation in business environment might potentially be an important factor for explaining differences in firms' entry, growth and productivity and, consequently, regional economic development and prosperity (Frijters \& Nemanja, 2016).

Further it was analysed a covariance coefficient and correlations among selective variables. There are positive relations among crude oil prices, inflation and an exchange rate movement, while negative correlations are among budget debt and cumulative debt against all other variables (Table 3).

Table 3: Coefficient Covariance Matrix

\begin{tabular}{|c|c|c|c|c|c|}
\hline & BRENT & INFLATION & RUB_EUR & BUDGET_DEBT & CUMM_DEBT \\
\hline BRENT & 0.0013 & 0.0001 & 0.0008 & 0.0022 & 0.0008 \\
\hline INFLATION & 0.0001 & 0.0037 & 0.0002 & -0.0016 & -0.0009 \\
\hline RUB EUR & 0.0008 & 0.0002 & 0.0061 & -0.0016 & -0.0009 \\
\hline BUDGET_DEBT & 0.0022 & -0.0016 & 0.0096 & 0.0451 & 0.0040 \\
\hline CUMM_DEBT & 0.0008 & -0.0009 & 0.0016 & 0.0040 & 0.0015 \\
\hline
\end{tabular}

Source: Own calculation (Eviews), 2017.

Commodity exporters are usually strongly affected by fluctuations in global markets, what is valid for the Russia economy as well. There is strong evidence that oil prices and exchange rates are related over the long-run. There is also a fair amount of evidence for various short-run linkages and spillovers between both markets at daily and monthly frequencies. According to study of Buetzer et al. (2016), exchange rate movements are not a silver bullet for understanding or forecasting the price of oil, and vice versa, and neither is a substitute for supply or demand factors. However, each contains potentially useful information for forecasting the other and should be taken into account, particularly over the short-run. The oil price-exchange rate relationship is evolving over time and has recently become more volatile. The change in monetary policy and the financialization of commodity markets offer potential explanations for the intensified relationship.

Disentangling oil supply and demand factors is also quite important since most studies analyse the relationship between the oil price and exchange rate without separating oil demand and supply factors Such a distinction is of great importance for a theoretical underpinning of the transmission channels from exchange rates to oil prices (Turhan et al. 2014). The understanding of the exchange-rate pass-through of oil exporters potentially explains the timevarying ties between exchange rates and oil prices. Related to the issue of supply and demand, it also seems quite important to address the role of common factors, such as monetary policy drivers. At a minimum one should include these factors in an empirical investigation, while the optimal solution is an evaluation of potential indirect transmission channels. Policy announcements have already been identified as a potential driver of exchange rate volatility (Conrad \& Lamla, 2010) and exchange rate expectations (Ferraro et al. 2015), (Beckmann \& Schüssler, 2016) while there has been much less written about their effect on oil prices. 
Next we try to forecast the price development of analysed Russia GDP for the next year, while taking into account all independent variables used in the model. A forecast function in EViews software was used methodologically. The results show a minor upward trends in the coming months after reaching a floor in 2015. The economic and fiscal initiatives of Putin administration and currently raising oil prices may help to maintain the growing tendency of Russian economy in next period (OECD, 2017). The next figure below summarises the model output for the Russia GDP forecasting.

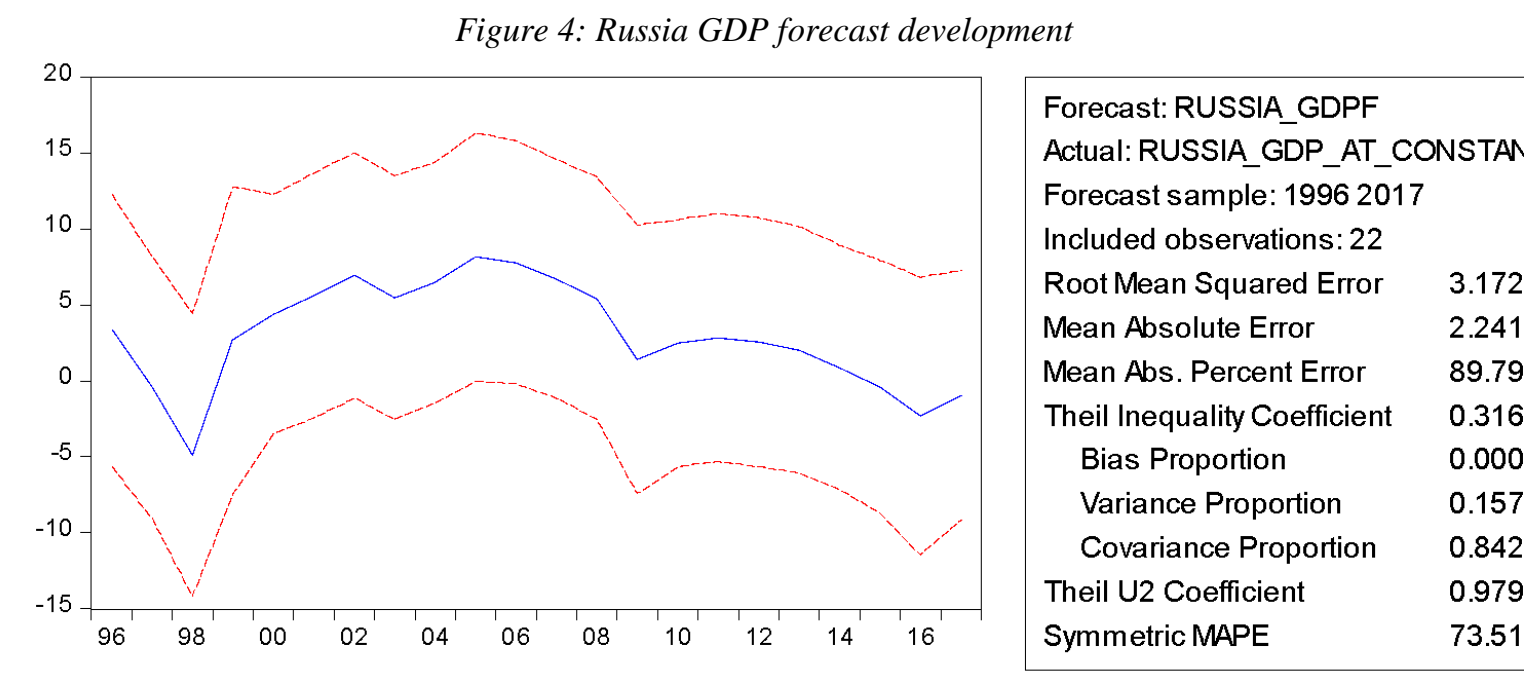

Source: Own calculation (Eviews), 2017.

\section{Discussion}

The Russia economy is projected to rebound from a deep recession on the back of stronger oil prices, higher wages and lower interest rates, which will boost household consumption and business investment. Russia's gross domestic product is forecasted for $1.7 \%$ year-to-year growth in 2017, the fastest growth in five years, as the country recovers from recession triggered in 2014 by the oil collapse and aggravated by western sanctions. The poverty rate will gradually decline as the labor market strengthens and inflation abates further.

Structural bottlenecks hamper the diversification of production, and the relatively strong rubble and continued sanctions will restrain non-oil exports. The value of the rubble against dollar is closely tied to the price of oil, Russia's main export. This has been confirmed by the studies of Granville \& Mallick (2010), Bodenstein et al. (2011), Bodard et al. (2012), Ono (2014) and Reboredo \& Rivera-Castro (2013).

Revision to the inflation forecast for 2017 shows the effect of monetary policy to bring price growth into line with Russia's 4\% target rate (Russian Central Bank, 2016). The slow reduction in inflation expectation has weighed on consumer sentiment, which lags behind the broader economic recovery. Monetary policy should be eased to support growth, but cautiously to avoid a rebound of inflation. In spite of swing in the increased outflow of the private capital and widened deficit in services, the current account of the balance of payments forecast for the whole year 2017 show minor surplus, as well as for the year 2018 .

Fiscal tightening, due to spending cuts, might jeopardize the recovery. Additional revenue could come from a higher VAT rate, taxes on the oil, gas sector and real estate, as well as by broadening the personal income tax. At the same time, funding is needed for large public investments in education, innovation and infrastructure. Institutional reforms would help lift longer term growth. The economy remains relatively closed, as international sanctions hamper 
higher value added in non-oil activities (Fagereng et al., 2018). The gains from globalization rest in oil revenues which are unevenly distributed across regions and income groups. According to study of Kudrin \& Sokolov (2017) and Deed \& Hodula (2016) reforming the tax system and investing the gains from higher oil prices in education and infrastructure would help diversify the economy, create more quality jobs and make globalization beneficial for all. Over the longer term growth is expected to continue lagging behind the world average unless the government adopts decisive structural reforms to boost investment.

\section{Conclusion}

This paper investigated the link between the Russia GDP and selected independent variables (Brent crude oil, consumer price index, real effective exchange rate RUB/EUR, government yearly budget debt to GDP and cumulative debt to GDP). We relied on the multiple regression method to establish whether the correlation among dependent and independent variables would capture their mutual relation. Our main findings can be summarized as follows. The selected variables imbedded into model describe the dependent variable for almost $60 \%$. Generally this number should be higher, but in a case of Russia, the other, mainly non-measurable qualitative factors amounts for remaining $40 \%$ of the GDP development. The output from the model confirmed, that the key role in a direction of Russia GDP play oil and commodity prices, their recovery would immediately help to stabilize the state budget and export revenues.

The other aspect of GDP growth (not captured by our model) is connected with the specific feature of the Russia economy. Despite the change of system from a command economy to a market economy, the institutions that normally support market allocation are weak, and in many ways they are overruled by the informal institutions surviving from the Soviet era. That Russia's institutions are deficient is reflected in the Worldwide Governance Indicators (World Bank, 2016). The WGI project constructs aggregate indicators of six broad dimensions of governance: political stability and absence of violence/terrorism; voice and accountability; government effectiveness; regulatory quality; rule of law; and control of corruption. When these indicators are studied over time, it is found that in Russia they have generally been low, that they improved up to the early 2000s, but that since 2004 there has been a marked deterioration in vital institutions (Oxenstierna, 2016; Bodart et al., 2012). Weak institutions create scope for manual management of economic matters, which is also a reason why institutions need to be kept weak - so that political goals rather than economic goals can be pursued (Gujsan, 2018).

Risks, both on the upside and downside, relate to oil prices and the geopolitical environment. Revenues from oil exports and overall growth may increase if oil producers achieve permanent supply restrictions and an ensuing price increase. Oil prices may, on the other hand, decline again if supply agreements break down and/or if swing producers are in a position to react swiftly to supply shortage (Baumeister et al., 2014). On the geopolitical side, sanctions are projected to remain, with both a possibility that they are strengthened if the Ukrainian crisis escalates, but also a possibility that they are lifted once a durable peace agreement is negotiated (Kaczmarska, 2018).

\section{Acknowledgment}

The presented working paper is an output of the scientific grants VEGA n. 1/0007/16 The impact of the global economic developments and trends in the direction of the euro area economy on financial management of business entities in Slovakia and VEGA no. 1/0010/17 Controlling in Slovak enterprises practice in the context of psychological aspects of perceiving its benefits and barriers by internal stakeholders. 


\section{References}

Baumeister, C., Kilian, L. \& Lee, T.K. (2014). Are There Gains from Pooling Real-Time Oil Price Forecasts? Energy Economics, 46, 33-43.

Beckmann, J. \& Schussler, R. (2016). Forecasting Exchange Rates Under Parameter and Model Uncertainty. Journal of International Money and Finance, 60, 267-288.

Bikar, M. (2013). The Trends of the Development of the Russian Economy. International Journal of Science, Commerce and Humanities, 1(7), 102-111.

Bodart, V., Candelon, B. \& Carpantier, J.-F. (2012). Real Exchanges Rates in Commodity Producing Countries: A Reappraisal. Journal of International Money and Finance, 31(6), 1482-1502.

Bodenstein, M., Erceg, C.J. \& Guerrieri, L. (2011). Oil Shocks and External Adjustment. Journal of International Economics, 83(2), 168-184.

Bogetic, Z. \& Olusi, O. (2013). Drivers of Firm-Level Productivity in Russia's Manufacturing Sector. World Bank Policy Research Working Paper 6572, 29.

Bouoiyour, J., Selmi, R., Tiwari, A. K. \& Shahbaz, M. (2015). The Nexus Between Oil Price and Russia's Real Exchange Rate: Better Paths Via Unconditional Vs Conditional Analysis. Energy Economics, 51, 54-66.

Buetzer, S., Habib, M.M. \& Stracca, L. (2016). Global Exchange Rate Configurations: Do Oil Shocks Matter? IMF Economic Review, 64(3), 443-470.

Conrad, C. \& Lamla, M.J. (2010). The High-Frequency Response of the EUR-USD Exchange Rate to ECB Communication. Journal of Money, Credit and Banking, 42, 1391-1417.

Deed, O. \& Hodula, M. (2016). Sovereign Default Risk and State-Owned Bank Fragility in Emerging Markets: Evidence from China and Russia. Post-Communist Economies, 28 (2), 232-248.

Fagereng, A., Guiso, L. \& Pistaferri, L. (2018). Portfolio Choices, Firm Shocks, and Uninsurable Wage Risk. The Review of Economic Studies, 85(1), 437-474.

Ferraro, D., Rogoff, K. \& Rossi, B. (2015). Can Oil Prices Forecast Exchange Rates? an Empirical Analysis of the Relationship Between Commodity Prices and Exchange Rates. Journal of International Money and Finance, 54, 116-141.

Frijters, P. \& Nemanja, A. (2016). Can Collapsing Business Network Explain Economic Downturns? Economic modelling, 54, 289-308.

Gaddy, C.G.W. \& Ickes, B.W. (2010). Russia after the Global Financial Crisis. Eurasian Geography and Economics, 51(3), 281-311.

Gonzalez, A., Iacovone, L. \& Subhash, H. (2013). Russian Volatility: Obstacle to Firm Survival and Diversification. World Bank Policy Research Working Paper 6605, 36.

Granville, B. \& Mallick, S. (2010). Monetary Policy in Russia: Identifying Exchange Rate Shocks. Economic Modelling, 27(1), 432-444.

Gurvich, E. (2013). Long-Term Development Prospects for the Russian Economy. Ekonomicheskaya Politika, 3 , 7-32.

Gujsan, C. (2018). Of Political Resurrection and 'Lost Treasures' in Soviet and Russian Politics. Europe-Asia Studies, 70(9), 1381-140.

Hair, J.F., Black, W.C, Babin, B.J. \& Anderson, R.E. (2010). Multivariate Data Analysis, 7th Edition. New Jersey, USA: Pearson Education.

Jacks, D. (2013). From Boom to Bust: A Typology of Real Commodity Prices in the Long Run. NBER Working Paper No. 18874, 62.

Kaczmarska, K. (2018). EU-Russia Relations in Crisis. Understanding Diverging Perceptions. Europe-Asia Studies, 70(9), 1531-1533.

Kohlscheen, E., Avalos, F. H. \& Schrimpf, A. (2016). When the Walk is not Random: Commodity Prices and Exchange Rates. International Journal of Central Banking, 13(2), 121-158.

Kudrin, A. (2013). The Influence of Oil and Gas Exports on Russia's Monetary Policy. Voprosy Ekonomiki, 3, 419.

Kudrin, A. \& Gurvich, E. (2015). A New Growth Model for the Russian Economy. BOFIT Policy Brief, No.1, Bank of Finland, Institute for Economies in Transition, 1-35. [Online] Available at: http://www.eeg.ru/files/lib/Kudrin-Gurvich\%20(BOFIT-2015).pdf

Kudrin, A. \& Sokolov, I. (2017). Fiscal Maneuver and Restructuring of the Russian Economy. Russian Journal of Economics, 3(3), 221-239.

Matyeeva, A. (2018). Russia's Power Projection after the Ukraine Crisis. Europe-Asia Studies, 70(5), 711-737.

Mau, V. (2016). Anti-crisis Measures or Structural Reforms: Russian Economic Policy in 2015. Russian Journal of Economics, 2, 1-22. 
OECD (2017). Russian Federation-Economic Forecast Summary. [Online]. Available at: http://www.oecd.org/eco/outlook/economic-forecast-summary-russia-oecd-economic-outlook-june-2017.pdf

Ono, S. (2014). Causality Relationship Among Oil Price, Stock Index and Exchange Rate: Evidence from Russia. Acta Slavica Iaponica, 35, 87-107.

Ono, S. (2017). Financial Development and Economic Growth Nexus in Russia. Russian Journal of Economics, $3(1), 321-332$.

Oxenstierna, S. (2016). Russia's Defense Spending and the Economic Decline. Journal of Eurasian Studies, 7(1), 60-70.

Papava, V. (2018). Catching Up and Catch-Up Effect: Economic Growth in Post-Communist Europe (Lessons from the European Union and the Eastern Partnership States). European Journal of Economic Studies, 7(2), $109-125$.

Reboredo, J. \& Rivera-Castro, M.A. (2013). A Wavelet Decomposition Approach to Crude Oil Price and Exchange Rate Dependence. Economic Modelling, 32(C), 42-57.

Reisinger, W. \& Moraski, B. (2013). Deference or Governance? A Survival Analysis of Russia's Governors under Presidential Control. Russia's Regions and Comparative Subnational Politics, W. Reisinger (ed.), London: Routledge, 40-62.

Sharafutdinova, G. \& Kisunko, G. (2014). Governors and Governing Institutions: A Comparative Study of StateBusiness Relations in Russia's Regions. World Bank Policy Research Working Paper 7038, 46.

The Central Bank of the Russian Federation (2016). Monetary policy report. [Online]. Moscow, 58. Available at: http://www.cbr.ru/Eng/publ/ddcp/2016_01_ddcp_e.pdf.

The Central Bank of the Russian Federation (2017). External Debt of the Russian Federation in Domestic and Foreign Currencies. [Online]. Available at: https://www.cbr.ru/eng/statistics/?Prtid=svs\&ch=ITM_4879\#CheckedItem.

Turhan, M.I., Sensoy, A. \& Hacihasanoglu, E. (2014). A Comparative Analysis of the Dynamic Relationship Between Oil Prices and Exchange Rates. Journal of International Financial Markets, Institutions and Money, 32(C), 397-414.

Tuzova, Y. \& Quayum, F. (2016). Global Oil Glut and Sanctions: The Impact On Putin's Russia. Energy Policy, 90, 140-151.

World Bank (2016). Worldwide Governance Indicators. [Online]. Available at: https://data.worldbank.org/datacatalog/worldwide-governance-indicatorsu.

World Bank (2017). Foreign direct investment, net inflows. [Online]. Available at: https://data.worldbank.org/indicator/BX.KLT.DINV.CD.WD?locations=RU.

Quandl (2017). Russia GDP Growth Annual Rate and Monthly Inflation Rate. Russia Government Budget as a \% of the GDP. Crude Oil Prices Brent and Exchange rate RUB/EUR. [Online]. Available at: https://www.quandl.com/data. 